\title{
The "Resurgent" Youth Voter in the United States
}

\author{
By Emanuel Gregory Boussios*
}

The 2008 U.S. Presidential election was a voting booth landslide for Democratic candidate Barack Obama over Republican candidate John McCain among 18-to-29 year old voters. This research analyzes 2008 National Election Pool exit poll data and seeks to explain why candidate Obama did so well in this election among this category of voters. The author finds that the evaluation of politicians' personalities is a critical part of explaining young voters' choice of candidate Obama as president. This research also found that young voters favored Obama because he was a Democratic Party candidate and liberal on political and social issues. In addition, the author finds some evidence of political parties reaching out to young voters as favorably affecting their voting choice which is important to analyze further given that both parties-in particular the Democratic Party-heavily favored the use of social media to do so. This cross-sectional analysis studies groups by age, party identification, and political ideology, in their general likelihood to support candidates in the 2008 presidential election. Lastly in analyzing young voter behavior from the 1992-2012 presidential elections, this research did not find evidence of a strong turnout of youth voters translating into an advantage for Democratic presidential candidates within that demographic group.

Scholars have stated (Shea and Harris, 2006) that recent trends in voting patterns and attitudes, the 2000 election in particular, have pointed to the withdrawal of young citizens from politics that has been rapid, deep, and broad. Explanations for young voter withdrawal have been contentment, apathy (Shea and Harris, 2006), cynicism, and the feeling of alienation from the political system (Patterson 2002, in Shea and Harris 2006). Other studies have shown that youth, especially those from diverse communities lack a sense of civic duty, a known driver to the polls (Campbell, 2008). In general, young voters do not see their citizenship as an opportunity for involvement, they do not know how or where to get the information or skills they need for greater participation in civic life, and above all, they just do not make it to the polls on Election Day (Moffett and Albowicz, 2003).

The outcome of the 2008 U.S. presidential election was indeed, historically speaking, quite extraordinary. In the 2008 election, In the 2008

\footnotetext{
${ }^{*}$ Visiting Scholar, Saltzman Institute for War and Peace, Columbia University- School of International Public Affairs, USA and Professor, Department of Sociology and Social Work, SUNY-Nassau Community College, USA.
} 
election, Democratic presidential candidate Barack Obama received its strongest support from the 18-to-29 year-old voting bloc; more than two-thirds of these voters cast their ballot for the Obama/Biden ticket over Republican presidential candidate Senator McCain, i.e. a 34 point advantage ${ }^{1}$. On the aggregate, $49 \%$ of adults 30 and over voted for candidate Obama with younger voters being at $66 \%$-- a notable difference of 17 points. Candidate Obama received a significant advantage in the 2012 presidential election as well, with a 60-to-37 percent outcome, bettering candidate Romney among young voters by 23 points $^{2}$. In recent decades, only incumbent presidential candidate Bill Clinton in the $1996^{3}$ elections garnered a voting advantage that was substantial, with a 19 point advantage 4 of the younger vote over Bob Dole. Even more striking is that candidate Obama had a 25 point Democratic advantage over candidate Clinton in $1992^{5}$ - a 34 point advantage for Obama versus a 9 point advantage for Clinton ${ }^{6}$. In fact, Obama's performance was the strongest in history since this voting bloc expanded to include 18-20 year olds in 1972 . Comparably, in the 2000 and 2004 elections, Democratic presidential candidates Al Gore and John Kerry garnered a 1 and 8 point advantage over their Republic opponents respectively ${ }^{7}$. Voter turnout in the ' 08 election among young voters was substantially higher than the previous three presidential elections with the subsequent 2012 election maintaining a similar momentum. The 2008 election turnout - 53\% — was nearly 5 percentage points higher than in the 2004 election, 11 percentage points higher than the 2000 election, and nearly a 15 percentage point increase from the 1996 election (see Table 1 ). The voter turnout was the same in percentage terms from the 1992 election (53\%); approximately 23 million young voters were mobilized compared to just over 20 million in 1992. The presence of a strong third party candidate-Ross Perot - may have altered the outcome of the youth vote in the 1992 and 1996 elections by taking some votes from the Democratic presidential candidates since Ross Perot was popular among young voters. However, the subsequent outcome in the 2000 election did not favor the Democratic candidate with a much weaker third party candidate (see Figure 1).

\footnotetext{
${ }^{1}$ http://www.ropercenter.uconn.edu/elections/how_groups_voted/voted_08.html

${ }^{2}$ http://www.ropercenter.uconn.edu/elections/how_groups_voted/voted_12.html

${ }^{3}$ In addition, Reform candidate Ross Perot gathered 9 percent of the total youth vote in 1996.

${ }^{4}$ http://www.ropercenter.uconn.edu/elections/how_groups_voted/voted_96.html

${ }^{5}$ In the 1992 election, Independent presidential candidate Ross Perot received 19 percent of the youth vote.

${ }^{6}$ http://www.ropercenter.uconn.edu/elections/how_groups_voted/voted_92.html

${ }^{7}$ Green Party candidate Ralph Nader received 5\% of the youth vote in the 2000 presidential election, and $<1 \%$ in the 2004 election.
} 
Table 1. Youth Voter Turnout, ages 18-29 years, for Presidential Elections 1996-2012

\begin{tabular}{|cccc|}
\hline Year & $\begin{array}{c}\text { Youth Voter Turnout } \\
\text { Estimated by CIRCLE }\end{array}$ & $\begin{array}{c}\text { Percentage point change since } \\
\text { previous election }\end{array}$ & $\begin{array}{c}\text { Number of young } \\
\text { people who voted }\end{array}$ \\
$\mathbf{1 9 9 2}$ & $53 \%$ & $-16 \%$ & 20.4 million $^{1}$ \\
$\mathbf{1 9 9 6}$ & $37 \%$ & +4 & 14.5 million $^{2}$ \\
$\mathbf{2 0 0 0}$ & $41 \%$ & +7 & 16.2 million $^{2}$ \\
$\mathbf{2 0 0 4}$ & $48 \%$ & $+4-5$ & 19.4 million $^{2}$ \\
$\mathbf{2 0 0 8}$ & $52-53 \%$ & -3 & $22.8-23.1$ million $^{3}$ \\
$\mathbf{2 0 1 2}$ & $49-50 \%$ & & $22-23$ million $^{4}$ \\
\hline
\end{tabular}

1.The estimated number of young people who voted in 1992 was calculated using the number of ballots cast in the United States (aggregated from data provided by local election officials).

2.The estimated number of young people who voted in 1996, 2000 and 2004 were calculated using the number of ballots cast in the U.S. (aggregated from data provided by local election officials) and the youth share of those who voted, as reported by exit polls. ${ }^{3}$ The estimated number of young people who voted in 2008 was calculated using a projection of the total number of ballots cast in the US and the youth share of those who voted, as reported by exit polls. Special thanks would like to be extended to CIRCLE for providing this data.

3. http://www.civicyouth.org/youth-turnout-rate-rises-to-at-least-52/ http://www.eric.ed.gov/PDFS/ED484021.pdf

4.http://www.civicyouth.org/youth-turnout-at-least-49-22-23-million-under-30-voted/

This research hypothesizes: (1) young voters disproportionally voted for the Obama/Biden ticket over the McCain/Palin ticket in 2008 because they were more likely to be contacted by the Democratic Party than the Republican party, (2) young voters disproportionally voted for the Obama/Biden ticket over the McCain/Palin ticket in 2008 because they are more likely to identify with the Democratic Party and self-identify as liberals, (3) young voters disproportionally voted for the Obama/Biden ticket over the McCain/Palin ticket in 2008 because they were more attracted to candidate Obama's than McCain's personal and leadership qualities.

Candidate Obama's campaigning style, more so than candidate McCain, heavily relied on the use of social media/technology to reach out to the young voter base. In addition, the young cohort of voters were politically active in the 2008 election. For instance, in contested states $28 \%$ of young voters reported attending a campaign event (Horowitz and Keeter, 2008). Perhaps the reason being was that, unlike in previous elections, youth were targeted heavily, especially in battle ground states. In Nevada, a key swing state, for instance, $61 \%$ of voters under thirty had been contacted by the Obama campaign, whereas McCain reached only $26 \%$ of this demographic (Horowitz and Keeter, 2008) and, in general, the Obama campaign was known to heavily court youth voters. Nearly a quarter of under 30 voters said that someone [from a political 
party] had contacted them (Horowitz and Keeter, 2008). For the first time, presidential candidates sent text messages to cell phones. One recent study found that text/SMS messages increase young voter turnout by $4.6 \%$ (Nairne and Soule, 2009). A PEW study found that $46 \%$ of adults used the internet, email and text messaging for political purposes in this election (Nairne and Soule, 2009). However, this was especially true for youth. Among Americans under $30,66 \%$ of internet users have a social networking profile.

Half of young social networking users used their personal profiles to get or share information about the campaign (Nairne and Soule, 2009). Overall, Obama supporters were more likely to get political news and information online (65\% vs. 56\%), including watching debates, speeches, or reading position papers and transcripts (Nairne and Soule, 2009). Obama's use of new technology seemed to connect very well with young voters.

Several of the personal qualities include Obama's likeability and his competence as a leader. The literature suggests that voters are likely to mobilize and vote for a candidate based on a candidate's personal traits and an individual voter's political predispositions (Caprara, Barbaranelli, Zimbardo, 2002). According to Caprara et al (2002) judgments about candidates are structured around particularly central and relevant traits, such as competence, leadership, integrity, and empathy, with competence and leadership receiving special emphasis due to the political nature of the task. Moreover, "these judgments can be influenced by political predispositions such as ideology, partisanship, and political preferences" (Rahn et al., 1990, p. 139). According to Pierce (1993), personal traits are not necessarily linked to the political parties, ideologies, and issues in the same way that these three latter sets of factors are interrelated. Candidate traits need not be related to politics, whereas parties, ideologies, and issues are inherently political; thus, candidate traits require less sophistication to understand and incorporate into the voting decision. Furthermore, candidate traits are very accessible to voters (Pierce, 1993). Patterson (1980) and others (Brady \& Hagen, 1986; Brady \& Johnston, 1987) have found that the media focus on the horse-race aspect of the campaign and on candidate traits rather than on issues.

In The American Voter, Campbell, Converse, Miller, and Stokes (1960/1980, p. 128) characterizes political parties as 'a supplier of cues by which the individual may evaluate the elements of politics.' Political scientists have long called this kind of voting behavior, based on a candidate's political party affiliation, as party-line voting. That is, this formulation suggests that most people follow the cues provided by their most salient political reference group - their party - and that they follow, in a general fashion, the party line as a result (Lunch and Sperlich, 1979). Information about candidates' party affiliations or party ties can shape opinion-holding on candidates (Mondak, 1993a); the direction of citizens' preferences (Jacoby, 1989; Mondak, 1993b; Squire and Smith, 1988); and perceptions of candidates' issue positions (Conover and Feldman, 1989). Popkin (1994), for example, argues that voters use shortcuts such as party affiliation and personal information about the candidates to reduce their uncertainty about candidates; he calls this mode of 
reasoning 'low-information rationality, or gut reasoning' (in Kam, 2005, p. 163-164).

\section{Methods $^{1}$}

This research is a cross-sectional analysis of groups by age, party identification, and political ideology, in their general likelihood to support candidates in the 2008 presidential election. Binary logistic regression was the statistical test utilized to analyze the data. The purpose of calculating adjusted or 'predicted' probabilities - which are simply alternative presentations of results derived from binary logistic regressions - is to provide an intuitively understandable method of controlling for other factors that might systematically affect certain groups in a particular way (Bowen and Bok, 1998). For instance, young voters aged 18-29 are much more likely to support Obama than voters 30 and over. Democrats are also much more likely to support Obama than other partisans. Thus, in proportion to voters 30 and over, if younger voters are much more likely to be Democrats, then their support for Obama will be higher than older voters. It is desirable, then, to 'adjust' political party affiliation to control for this fact. When comparing adjusted rates for younger and older voters, as is done in this research, one is able to analyze outcomes for these two groups on the assumption that they are equivalent in other respects (political party affiliation, political ideology) except for their age. The analysis here is based on a model with the dependent variable as a vote for the Democratic candidate. Observing (an example as presented by Bowen and Bok, 1998, using similar methodology) that younger and older voters support the candidates at different rates, one can answer the following question: If the two age groups had identical political party affiliations, and were also the same on political ideology, would they still support Obama at different rates?

This research calculates adjusted probabilities using the results of the logistic regression analysis described above. To compute an overall adjusted probability (for the 'average' person in a particular model) one substitutes the parameter estimates for each element in the vector $\beta$ and multiplying them by each variable's mean value.

$$
\text { Probability }\left[Y_{\mathrm{i}}=1\right]=P_{\mathrm{i}}=\frac{1}{1+\mathrm{e}^{-(\alpha+\beta X i)}}
$$

Where $\mathrm{Pi}$ is the probability that $\mathrm{Yi}$, the outcome in question, will take place for the $i$ th individual, e represents Euler's constant (which is approximately equal to 2.718), $\alpha$ is the intercept parameter (or constant term), $\mathrm{Xi}$ is a vector of explanatory (independent) variables, and $\beta$ is a vector of

\footnotetext{
${ }^{1}$ Thanks to Bowen and Bok (1998) for their excellent explanation of adjusted probabilities.
} 
parameter estimates for each of the independent variables in the vector $\mathrm{Xi}^{1}$. Dividing the expected probability that an event will occur by the probability that it will not occur, and transforming this equation by taking logs results in:

$\operatorname{Logit}(\mathrm{Pi})=\log (\mathrm{Pi} / 1-\mathrm{Pi})=\alpha+\beta \mathrm{Xi}$

To obtain the parameters $\alpha$ and $\beta$, maximum likelihood estimation is used to find the set of parameters that make it most likely that the observed outcomes would have occurred. The logarithm of the odds that a particular outcome will occur (sometimes referred to as the log odds ratio) is a linear function of the independent variables.

The $\mathrm{P}$ is the probability of an individual voting, a typical (simplified) logistic model might be:

Logit $(\mathrm{P})=\alpha+\beta \mathrm{i}$ YOUNG $+\beta \mathrm{i}$ DEMOCRAT

Here, YOUNG equals one for 18-29 year old voters and zero for voters age 30 and over, and DEMOCRAT equals one for respondents of this affiliation and zero for all others. The parameters $\alpha 1, \beta 1, \beta 2$, and $\beta 3$ can be estimated with statistical software, and the results allow us to predict the logarithm of the odds of supporting candidate Obama. This can be converted to an estimate of the probability of supporting candidate Obama by using the first equation.

\section{Results and Discussion}

The Youth Voter and Party Identification since the 2008 Election

As evident from the data in Figures 1 and 2, although 18-29 year old voters since 1992 have generally identified themselves more with the Democratic Party than the Republican Party this has not always translated to a Democratic advantage in presidential elections (Figure 2 includes Democratic and Republican 'leaning' voters). As evident from the data in Figures 1 and 2 for 18-29 year olds, in the 1992 election, Clinton enjoyed a 9 point advantage in the polls despite not having the advantage of these voters being registered with his party at a greater rate. In the 1996 election, Clinton had a substantial 19 point advantage in the polls, which was considerably more than the 6 point Democratic edge on among those registered in his party. In the 2000 election, neither major party had an advantage in the presidential polls, although young voters were more likely to identify themselves as Democrats. A critical piece of this picture was that the subsequent outcome in the 2000 election did not favor the Democratic candidates absent a strong third party candidate. In the 2008 election, youth were much more likely (a 25\% percentage point difference) to identify with the Democratic Party than the Republican party and

${ }^{1}$ This section is based on a predicted probability explanation seen in Pindyck and Rubinfield 1991, pp. 258-261. 
even more likely to vote Democratic (a $34 \%$ percentage point difference). According to Keeter and Horowitz (2008), because of this, this cohort of young voters should be called 'Gen Dems.'

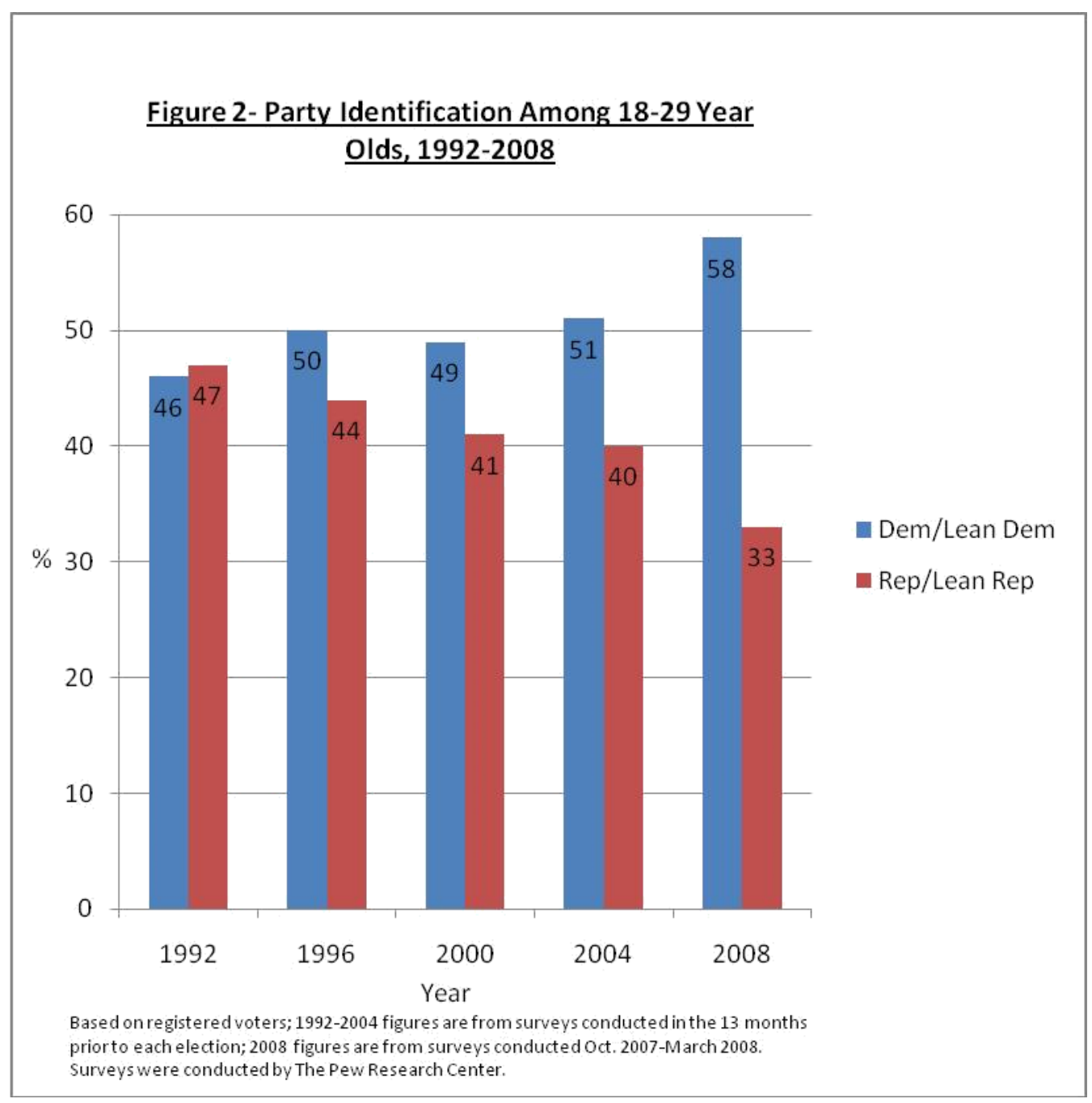

The data suggests that although the party-line voting theory is important in determining voter choice, it does not always help to explain voting behavior among this voting bloc. Young voters may cast a vote different than their (registered) party allegiance, i.e. a registered Republican may decide to vote for a Democratic president. In addition, some young voters (whether Democratic or Republican leaning) may choose to stay home. The outcome could be, for example, that a particular election may bring out more registered Republican voters then registered Democratic or Independent voters. As seen in the previous discussion on voter turnout, a larger voter youth turnout does not always translate into a Democratic advantage in the polls. 


\section{Opinion by Demographic Group for the 2008 Presidential Election}

Table 2 gives the predicted probabilities for Obama in the 2008 election by controlling for political party, controlling for political ideology, controlling for political party and political ideology, and controlling for party contact. Although nearly all of the variables were statistically significant at the .001 level because of the very large sample sizes, the substantive differences will be discussed in greater detail in the following analysis.

Table 2. Predicted Probabilities of Support for Candidate Obama in the 2008 Presidential Election, by Age Categories

$\begin{array}{llllll}\text { \% stating } & \text { controlling } & \text { controlling } & \text { controlling } & \text { controlling } & \text { controlling for } \\ \text { Supportfor } & \text { for } & \text { for } & \text { for party } & \text { for political } & \text { political party, } \\ \text { Obama } & \text { political } & \text { political } & \underline{\text { contact }} & \text { party and } & \text { political ideology, } \\ & \text { party } & \underline{\text { ideology }} & & \text { political ideology } & \text { and party contact }\end{array}$

$\begin{array}{lllllll}\begin{array}{l}\text { Age }(\mathbf{n}=\mathbf{1 , 2 0 8}) \\ 18-29 \text { yrs }\end{array} & 66 & 76 & 73 & 82 & 78 & 76 \\ 30+\text { yrs } & 49(\text { diff.=17) } & 63(\text { diff.=13) } & 64(\text { dif.=9) } & 70(\text { diff.=12) } & 68(\text { diff.=10) } & 65(\text { diff.=11) }\end{array}$

Note: All figures have a chi-square significance of $(\mathrm{p}<.001)$ except when indicated otherwise in italics.

Support rates are predicted probabilities adjusted from binary

logistic regression results.

Source: 2008 National Election Pool

It is evident in Figure 3, except for the small advantage that McCain had over Obama of voters $60+$, that voters over the age of 30 are not more likely to have voted for McCain than Obama. Therefore, the competing hypothesis that perhaps the age differences were a result of McCain's stronger appeal to older voters does not hold true. Younger Americans are the group most likely to support the Democratic Party (see Figure 2). Are young voters more likely to support Obama in 2008 because they are Democrats and Democrats are more likely to vote for candidates in their own party? When controlling for political party affiliation in the 2008 election, the original 17 point difference in support of Obama between young voters and older voters is reduced to 13 points (Table 2). Are young voters more likely to support Obama in 2008 because they are liberals and liberals are more likely to vote for liberal candidates, such as the Democratic party candidates? When controlling for political ideology, the original 17 point difference between young voters and older voters is reduced to 9 points (Table 2). Are young voters more likely to support Obama in 2008 because the Democratic party was more likely to reach out to young voters then the Republican party? When controlling for party contact, the original 17 point difference between young voters and older voters is reduced to 12 points (Table 2). Although the difference was reduced, indicating that party contact 
had a minor effect, perhaps it matters more how the party messages (propaganda, etc) were delivered to these voters than whether these voters were contacted by either political party.

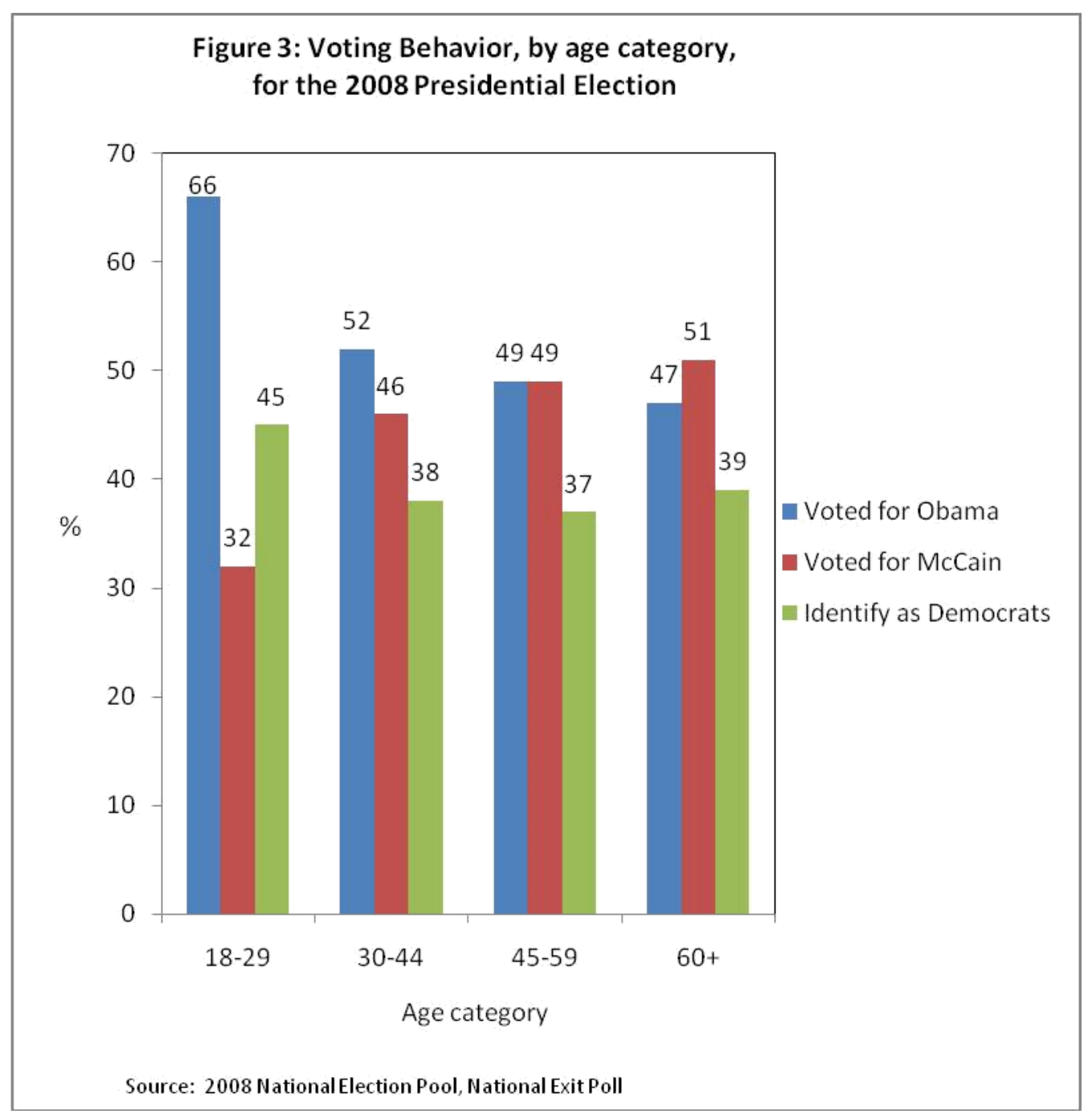

Since liberals are substantially more likely to be Democrats and Independents, and conservatives to be Republican, perhaps the correlation between political ideologies and party identification might explain such a large party difference that is found for this election among younger voters. Controlling for political ideology and political party did not wash out the differences in support for Obama in the 2008 election (10 point difference). By comparing younger and older voters, one can see that when people are 'made alike' on political ideology and political party affiliation, there is a difference in the attitudes of peoples of different ages in presidential voting in the 2008 election. Even when controlling for political ideology, political party, and party contact - whether or not the Obama (or McCain campaign) contacted them to vote - the original 17 point difference was reduced to an 11 point difference. 
Could there be an 'Obama effect' independent of party politics (partisanship, etc), that gave this candidate support from this cohort of voters? His energy, enthusiasm, excitability, and oratory skills seemed to have been influential in effecting young voters' choice. This is demonstrated in several of the responses young voters had on their opinions on candidate Obama in the exit polls (see Table 3).

Table 3. Personality and Non-personality Questions related to Candidate Obama in the 2008 Presidential Election by Age Category

\section{Voter category}

$\begin{array}{ll}\text { 18-29 year old Obama voter } & \begin{array}{l}30+\text { year } \\ \text { old Obama } \\ \text { Voter }\end{array}\end{array}$

Voter

Personality Questions

"[candidate is] in touch

with people like me"

“excited about what [candidate]

will do if elected president"

"concerned but not scared about what

[candidate] will do if elected president"

Right judgment

Bring about change

Cares about me

\section{Non-personality questions}

Shares my values

Right experience

Source: 2008 National Election Pool

Responses from several of the questions from the exit polls were equated with a few adjectives from the common list of 25 adjectives used for the evaluation of politicians' personalities (Caprera et al 2002). These questions, or 'personality questions' (see Table 3), are similar to the types of adjectives seen in their work (see Caprera et al, 2002). Young Obama voters (93\%) were just as likely as older Obama voters $(92 \%)$ to believe that 'candidate Obama is in touch with people like me', which equates to the adjective 'listens to the needs of voters.' This similar adjective was composed in the question 'if Obama 
cares about me', in which young Obama voters (16\%) and older Obama voters $(16 \%)$ were equally likely to agree on this question. Young Obama voters were much more likely $(73 \%)$ than older Obama voters $(55 \%)$ to be 'excited about what Obama will do if elected president', which equates to the adjective 'energetic and effective.' This similar adjective was also enterprised in the question 'concerned but not scared about what Obama will do if elected president' in which young Obama voters $(11 \%)$ were much less likely than older Obama voters $(22 \%)$ to agree with this statement. Young Obama voters were more likely to agree (67\%) than older Obama voters $(60 \%)$ that Obama could 'bring about change', which equates to the adjectives 'original, innovative, and creative.' As for the non-personality questions, older Obama $(19 \%)$ versus young Obama $(14 \%)$ voters were more likely to agree that Obama 'shares my values', but the groups did not differ on the question $(2 \%)$ of Obama 'having the right experience to lead.'

This final analysis correlated several factors emerging from young and older voters' personality evaluations of candidate Obama. Although young voters were more likely than older voters to answer favorably on most of Obama's personality questions, these correlations were moderate. However, the fact that some differences exist, in particular for questions related to seeing their candidate as 'energetic and effective' and 'original, innovative, and creative' indicates that when young voters evaluate the personalities of their own potential leaders, these schemata may serve as personal anchors that assimilate or pull some candidates into the latitude of voter acceptance or rejection. As a useful comparison, it was well known that Nixon and John F. Kennedy in their presidential campaigns benefitted from televised debates. It was believed, at the time, that potential voters were able to evaluate the personalities of these politicians (and their opponents) more readily with televised media, and it worked (as an electoral advantage) for both Nixon and JFK in their respective presidential contests. Further research on this is needed to see the degree of this rejection or acceptance based on a politicians' personality balanced with the importance of issue-based questions on youth voter choice.

\section{Conclusion and the 2012 Presidential Election}

This research reached a number of interesting conclusions. A large youth turnout in the polls does not always equal a Democratic advantage in presidential elections. In general, this voting bloc has taken on a unique character. In choosing the Democratic candidate in the 2000 and 2004 presidential elections, this voting bloc expressed candidate preferences distinct from the general voting population. In every election since 1972, young voters have preferred the candidate that won the presidential election and the popular vote. This voting bloc is no longer 'following' but has exhibited behavior distinct from that of their adult counterparts. Therefore, the finding in this research that party contact was relevant to whether or not a young voter goes out and votes - and whom they vote for - may indicate that the mobilization of 
these voters requires unique measures (and message).

Evidence from the 2008 election indicated that partisanship and political ideology is indeed important in determining voting behavior, but other factors were important as well. Controlling for partisanship in the 2008 election among voters only produced a minor reduction of Obama's youth advantage over older Obama voters. Seeing that these differences still exist in this later election between the voters demonstrates that other factors are important in the voting decision and/or partisanship is on the decline-in other words, voters weigh less the importance of what party they are registered as on their vote choice. A look at 'personality-type' questions in the 2008 election found that some differences did appear depending on the age group of the voter. Young voters are somewhat more likely than older voters to answer favorably on personality questions evaluating candidate Obama in the 2008 election. In other words, there is some indication in this research that there was a unique 'Obama effect' independent of party politics that encouraged young voters to vote for candidate Obama.

As for the events surrounding the 2012 presidential election campaign, young voters were, once again, a particular target for Obama (Henderson, 2012). Candidate Obama tried to energize the groups that flocked to his support in the 2008 campaign. About 23 million people under 30 voted in the 2012 election (Camina, 2012). Put another way: If Romney won half the under-30 crowd -- or if they didn't vote at all -- he would have won Florida, Ohio, Pennsylvania and Virginia (Camina, 2012). Peter Levine, director of research organization, said this kind of high turnout among young voters makes them 'an essential political bloc.' 'Right now, they form a key part of the Democrats' national coalition,' he said. 'Republicans must find a way to compete for their votes.' (Camina, 2012). Once again, after a decade of voter decline, the youth voter has reemerged as a critical piece of electoral politics in the United States with a unique voting character distinct of that of the other age voting blocs.

\section{References}

Bok, Derek and Bowen, William G. 1998. The Shape of the River. Princeton: Princeton University Press.

Brady, H. E. and Hagen, M. G. (1986). The 'horse-race' or the issues? What do voters learn from Presidential primaries? Paper presented at the Annual Meetings of the American Political Science Association, Washington, D.C.

Brady, H. E. and R. Johnston. (1987). What's the primary message: Horse race or issue journalism. In G. R. Orren and N. W. Polsby (Eds.). Media and Momentum: The New Hampshire Primary and Nomination Politics, Chatham, N. J.

Campbell, A., Converse, P. E., Miller, W. E., \& Stokes, D. E. (1960). The American Voter. New York: Wiley.

Campbell, David E. (2008) "Why We Vote: How Schools and Communities Shape Our Civic Life." Princeton University Press.

Caprara, Gian Vittorio. Barbaranelli, Claudio. Zimbardo, Philip G. (2002) When Parsimony Subdues Distinctiveness: Simplified Public Perceptions of Politicians' 
Personality. Political Psychology, 23, 77-95.

Conover, Pamela Johnston. Feldman, Stanley. (1989) Candidate Perception in an Ambiguous World: Campaigns, Cues, and Inference Processes. American Journal of Political Science, 33(4), 912-940.

Harris, Rebecca. Shea, Daniel M. Why Bother? Because Peer-to-Peer Programs Can Mobilize Young Voters PS: Political Science \& Politics (2006), 39: 341-345 Cambridge University Press

Jacoby, William G. 1989. "The Sources of Liberal-Conservative Thinking: Education and Conceptualization." Political Behavior 10:316-32.

Kam, Cindy D. (2005) Who Toes the Party Line? Cues, Values, and Individual Differences. Political Behavior, 27, 163-182.

Lunch, William L. Sperlich, Peter W. (1979) American Public Opinion and the War in Vietnam. The Western Political Quarterly, 32(1), 21-44.

Mondak, Jeffery J.1993a. "Nothing to Read: Newspapers and Information Acquisition in the American Electorate." Presented at the annual meeting of the Midwest Political Science Association, Chicago.

Mondak, Jeffery J.1993b. "Presidential Coattails and Open Seats: The District-Level Impact of Heuristic Processing." American Politics Quarterly21:307-19.

Patterson, T. E. (1980). “The Mass Media Election.” Praeger, N. Y.

Pierce, Patrick A. (1993). Political Sophistication and the Use of Candidate Traits in Candidate Evaluation. Political Psychology, 14, 21-35.

Rahn, W. M., Aldrich, J. H., Borgida, E., \& Sullivan, J. L. (1990). A social-cognitive model of candidate appraisal. In J. A. Ferejohn \& J. H. Kuklinski (Eds.), Information and democratic processes (pp. 136-159). Urbana, IL: University of Illinois Press.

Smith, N., Squire, Peverill. (1988) The Effect of Partisan Information on Voters in Nonpartisan Elections The Journal of Politics, 50, 169-179.

\section{Websites}

Albowicz, Kay. Moffett, Colin J. (2003, July). New Millennium Survey Update: 2003- 2004 Secretary of State Best Practices. Retrieved from: http://www.nass.org/index.php?option=com_content\&view=article\&id=13 $2 \&$ Itemid $=440$

Camia, Catalina. (2012, November 7) Study: About 49\% of young voters cast ballots Retrieved from: http://www.usatoday.com/story/theoval/2012/11/ 07/obama-romney-youth-vote-election/1690075/

Henderson, Nia-Malika. Obama courts young voters. Retrieved February 1, 2012, from Washington Post Website: http://www.washingtonpost.com/ blogs/election-2012/post/obama-courts-youngvoters/2011/10/25/gIQA9CYWHM_blog.html

Horowitz, Juliana. Keeter, Scott. (2008, Nov. 12). Young Voters in the 2008 Election. Retrieved from: http://pewresearch.org/pubs/1031/young-votersin-the-2008-election

Nairne, Jennifer. Soule, Suzanne. (2009, March 19-21). Civic Education and Youth Turnout in the 2008 Presidential Election: Data from Engaged 
Citizens, We the People Alumni. Retrieved from: http://www. civiced.org/pdfs/research/WPSA_Soule_Nairne.pdf

\section{Appendix: Question Wording in the Voter News Service and National Election Pool Exit Polls}

Party Contact (2008 only)

This is the question measuring party contact, "Did anyone call you or talk to you in

person on behalf of either major presidential campaign about coming out to vote?(1) Yes, for Barack Obama, (2) Yes, for John McCain, (3) Yes, for both Obama and McCain, or (4) No, I was not contacted.

\section{Political Party}

This is the question measuring political party, "In politics, as of today, do you consider yourself a Republican, a Democrat or an Independent?"

Political Ideology

This is the question measuring political ideology as a self-described measure, "How would you describe your political views? (1) Very conservative, (2) Conservative, (3) Moderate, (4) Liberal, or (5) Very liberal. 